\title{
PENGGUNAAN METODE EXPONENTIAL SMOOTHING UNTUK PERAMALAN PENJUALAN PRODUK GALVALUM (STUDI KASUS PADA TOKO ISTANA GALVALUM JEMBER)
}

\author{
SITI HUSNUL HOTIMA* \\ DEVA DAMARA \\ Program Studi Ilmu Administrasi Niaga \\ Sekolah Tinggi Ilmu Administrasi Pembangunan Jember \\ *Email: husnul@stiapembangunanjember.ac.id
}

\begin{abstract}
ABSTRAK
Penelitian ini bertujuan untuk menghitung metode Exponential Smoothing dengan alpha 0,1 0,5 0,9 dalam meramalkan penjualan untuk periode selanjutnya. Penelitian ini merupakan penelitian kuantitatif dengan pendekatan deskriptif yang menggunakan data sekunder yaitu data penjualan Toko Istana Galvalum Jember mulai Bulan Oktober 2017 sampai September 2018.

Hasil yang didapat dari penelitian ini antara lain hasil peramalan untuk produk Kanal $\mathrm{C} 1 \mathrm{~mm}$ yaitu menggunakan metode menggunakan metode Exponential Smoothing dengan alpha 0.9 dengan hasil peramalan untuk bulan Oktober 2018 sebesar 1006 unit. Hasil peramalan produk Kanal C 0,75 mm yaitu menggunakan metode Exponential Smoothing dengan alpha

0.9 dengan hasil peramalan untuk bulan Oktober 2018 sebesar 6547 unit.

Hasil peramalan produk Kanal C 0,6 mm yaitu menggunakan metode

Exponential Smoothing dengan alpha 0.1 dengan hasil peramalan untuk bulan Oktober 2018 sebesar 1564 unit. Hasil peramalan produk Reng yaitu menggunakan metode Exponential Smoothing dengan alpha 0.9 dengan hasil peramalan untuk bulan Oktober 2018 sebesar 15066 unit. Hasil peramalan

produk Baut Skrup yaitu menggunakan metode Exponential Smoothing dengan alpha 0.5 dengan hasil peramalan untuk bulan Oktober 2018 sebesar

112982 unit.

Keismpulan penelitian ini adalah peramalan yang memiliki nilai eror yang cukup rendah dan akurasi yang cukup baik dapat digunakan sebagai bahan pertimbangan dalam perencanaan pengadaan barang.
\end{abstract}

Kata Kunci: Peramalan Penjualan, Exponential Smoothing 


\section{PENDAHULUAN}

Usaha atau bisnis baja ringan di Indonesia mengalami perkembangan yang cukup pesat beberapa tahun belakangan ini, dengan berbagai format dan jenisnya. Di tengah kondisi perekonomian Indonesia yang sedang mengalami masa-masa sulit, namun bisnis di bidang baja ringan masih tetap dapat bertahan sebab setiap orang pasti membutuhkan misalnya untuk perumahan. Bisnis ritel baja ringan ini bahkan memiliki potensi jauh lebih berkembang, ini terbukti dengan menjamurnya usaha ini mulai dari kota-kota besar sampai ke kotakota kecil. Perkembangan bisnis ritel ini dikarenakan meningkatnya jumlah penduduk, perkembangan usaha manufaktur sehingga kebutuhan masyarakat juga meningkat dalam kualitas dan kuantitas, pergeseran budaya masyarakat yang semakin modern.

Saat ini konstruksi kuda-kuda dari bahan baja ringan tidak lagi seperti di era tahun 2000an karena pada masa itu konstruksi kuda-kuda dari baja ringan masih langka sehingga masih dapat dimonopoli dalam penjualannya oleh perusahaan tertentu, namun saat ini konstruksi kuda-kuda dari bahan baja ringan sudah merupakan industri rumahan sehingga tidak ada lagi monopoli yang mengakibatkan persaingan akan semakin ketat mulai dari harga, pelayanan, kualitas produk dan sistem penjualan.

Dalam penelitian ini penulis akan melakukan analisis terhadap peramalan penjualan pada Toko Istanan Galvalum Jember yang bergerak di bidang kontruksi dan menyediakan berbagai macam produk, salah satu produknya yang paling laris yaitu baja ringan (galvalum). Toko Istana Galvalum selain pengecer juga sebagai distributor dari produk Osaka Stell. Peramalan penjualan dilakukan karena sering terjadi kekurangan stok persediaan barang dan keterlambatan dalam mendatangkan barang tersebut. Permasalahan yang umum dihadapi oleh para pemilik perusahaan adalah bagaimana memprediksi atau meramalkan penjualan barang di masa mendatang dari data yang telah direkam 
sebelumnya. Berdasarkan data yang diperoleh, produk yang pernah terjadi kekurangan stok yaitu produk-produk dari baja ringan (galvalum). Fokus penelitian ini pada rangka atap (kontruksi kuda-kuda) yang terdiri dari produk Kanal C, Reng, dan Baut Skrup. Untuk produk Kanal C terdiri dari tiga jenis yaitu
Kanal C $1 \mathrm{~mm}$, Kanal C $0.75 \mathrm{~mm}$, dan Kanal C $0.6 \mathrm{~mm}$. Analisis ini menggunakan peramalan kuantitatif berdasarkan data histori penjualan selama satu tahun yaitu mulai bulan Oktober 2017 sampai september 2018. Berikut data-data yang mengalami kekurangan stok Toko Istanan Galvalum Jember:

Tabel 1. Data Stok Persediaan Produk Kanal C 1 mm

\begin{tabular}{|c|c|c|c|c|c|}
\hline No & Tanggal & $\begin{array}{c}\text { Persediaan } \\
\text { Awal }\end{array}$ & Masuk & Keluar & $\begin{array}{c}\text { Persediaan } \\
\text { Akhir }\end{array}$ \\
\hline 1 & $01 / 12 / 2017$ & 264 & - & - & 264 \\
\hline 2 & $04 / 12 / 2017$ & 264 & - & 84 & 180 \\
\hline 3 & $05 / 12 / 2017$ & 180 & 250 & - & 430 \\
\hline 4 & $08 / 12 / 2017$ & 430 & - & 92 & 338 \\
\hline 5 & $09 / 12 / 2017$ & 338 & - & 88 & 250 \\
\hline 6 & $12 / 12 / 2017$ & 250 & - & 106 & 144 \\
\hline 7 & $15 / 12 / 2017$ & 144 & 250 & 98 & 296 \\
\hline 8 & $17 / 12 / 2017$ & 296 & - & 96 & 200 \\
\hline 9 & $20 / 12 / 2017$ & 200 & 30 & 230 & 0 \\
\hline 10 & $23 / 12 / 2017$ & 0 & 250 & - & 250 \\
\hline 11 & $27 / 12 / 2017$ & 250 & - & 86 & 164 \\
\hline 12 & $29 / 12 / 2017$ & 164 & - & 95 & 69 \\
\hline 13 & $31 / 12 / 2017$ & 69 & - & - & 69 \\
\hline
\end{tabular}

Sumber : Data penjualan Toko Istana Galvalum, 2017 - 2018

Berdasarkan Tabel 1, stok persediaan produk kanal C $1 \mathrm{~mm}$ mengalami kekurangan stok pada tanggal 20 Desember 2017, dimana jumlah permintaan untuk produk tersebut sebesar 230 unit sedangkan stok persediaan yang ada hanya sisa 200 unit. Hal serupa juga terjadi untuk produk kanal C $1 \mathrm{~mm}$ di bulan Mei 2018.
Berdasarkan hasil observasi, stok persediaan barang pernah mengalami kekurangan stok dimana jumlah permintaan untuk produk lebih besar dari jumlah persediaan awal yang ada. Untuk mengatasi masalah seperti ini pihak toko biasanya mengambil barang dari mitra Toko Istana Galvalum yang juga menjual produk dari merek 
Osaka Stell untuk menutupi kekurangannya. Apabila peramalan atau prediksi ini diterapkan dalam bagian proses perencanaan pengadaan barang maka pihak perusahaan akan lebih terbantu dalam penjadwalan untuk mendatangkan barang, karena prediksi ini dapat memberikan solusi terbaik sehingga diharapkan risiko kesalahan yang disebabkan oleh kesalahan perencanaan dapat ditekan seminimal mungkin. Peramalan dilakukan dengan megunakan metode Exponential Smoothing dengan alpha ( $\alpha: 0.1 \alpha: 0.5 \alpha: 0.9)$, metode Exponential Smoothing digunakan karena berdasarkan data yang diperoleh bersifat acak atau fluktuasi. Metode Exponential Smoothing merupakan metode

\section{TINJAUAN PUSTAKA}

\subsection{Definisi Peramalan}

Menurut Heizer dan Render (2017:136) menyebutkan bahwa peramalan adalah seni dan ilmu untuk memprediksi kejadian di masa depan dengan melibatkan pengambilan data historis dan memproyeksikannya ke masa peramalan rata-rata bergerak dengan pembobotan, di mana $\alpha$ adalah sebuah bobot atau konstanta penghalusan yang dipilih oleh peramal yang mempunyai nilai antara 0 dan 1 .

Keberhasilan suatu bisnis menjadi suatu prioritas utama. Perusahaan dituntut untuk jeli melihat perkembangan pasar sehingga manajemen dapat memperkirakan apa yang akan terjadi dan mengambil keputusan secara tepat. Berdasarkan latar belakang di atas maka penulis tertarik mengadakan penelitian di Toko Istana Galvalum terkait dengan peramalan penjualan dengan menggunakan metode Exponential Smoothing.

mendatang dengan model pendekatan sistematis.

Stevenson

(2018:72) mendefinisikan peramalan sebagai input dasar dalam proses pengambilan keputusan manajemen operasi dalam memberikan informasi tentang permintaan di masa 
mendatang dengan tujuan untuk menentukan berapa kapasitas atau persediaan yang akan dibutuhkan untuk memenuhi permintaan.

Jadi, peramalan dapat diartikan sebagai pendekatan sistematis yang digunakan untuk menganalisa pola dari data historis penjualan untuk memproyeksikan permintaan dimasa mendatang sebagai dasar dalam membuat perencanaan jangka panjang perusahaan serta sebagai pertimbangan untuk beberapa keputusan yang terkait dengan kebutuhan kapasitas, persediaan, dan anggaran yang digunakan agar dapat memenuhi permintaan tersebut.

\subsection{Metode Peramalan}

Menurut Baroto (2002:27),
untuk membuat peramalan
permintaan harus menggunakan
suatu metode tertentu. Pada
dasarnya, semua metode peramalan
memiliki ide sama, yaitu
menggunakan data masa lalu untuk
memperkirakan atau
memproyeksikan data di masa yang
akan datang. Berdasarkan tekniknya,
metode peramalan dapat

dikategorikan ke dalam metode kualitatif dan kuantitatif.

1. Metode Kualitatif

Metode peramalan yang bersifat subyektif, karena dipengaruhi oleh faktorfaktor seperti intuisi, emosi, dan pengalaman seseorang. Heizer dan Render

mengklasifikasikan peramalan kualitatif dalam beberapa metode, yaitu:

a. Juri dari Opini Eksekutif. Pada metode ini data diperoleh dengan mengambil pendapat dari sekelompok manajer level puncak dan seringkali dikombinasikan dengan model-model statistik untuk menghasilkan estimasi permintaan kelompok.

b. Metode Delphi. Dalam metode ini karyawan menggunakan teknik menyebarkan kuesioner kepada para responden dan hasil survei tersebut dijadikan sebagai pengambilan keputusan sebelum peramalan dibuat.

c. Gabungan Tenaga Penjualan. Dalam pendekatan ini, setiap 


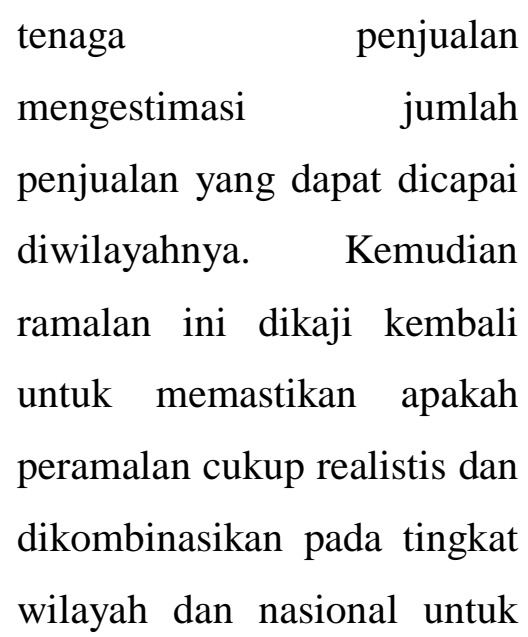

2. Metode Kuantitatif

Heizer dan Render (2017:139) menjelaskan bahwa metode forecast dilakukan dengan menggunakan model matematis yang beragam dengan data historis yang terkait dengan peramalan dan variabel sebab akibat untuk meramalkan permintaan. Analisis deret waktu ini sangat tepat dipakai untuk meramalkan permintaan yang pola permintaan di masa lalunya cukup konsisten dan akurat dalam periode waktu yang lama. Adapun metode yang dapat digunakan untuk menganalisis data tersebut, yaitu:
a. Naive Method (Pendekatan Naif)
Naive method merupakan teknik peramalan yang mengasumsikan forecast

memperoleh peramalan secara menyeluruh.

d. Survei Pasar Konsumen. Metode ini meminta masukan dari konsumen mengenai rencana pembelian mereka dimasa depan. Survei konsumen ini dapat dilakukan melalui percakapan informal dengan para konsumen.

permintaan periode berikutnya sama dengan permintaan pada periode sebelumnya, sehingga dapat diformulasikan sebagai berikut:

$F_{t}=Y_{t}-1$

keterangan:

$\mathrm{Ft}=$ peramalan permintaan periode berikutnya $\mathrm{Yt}-1=$ peramalan permintaan periode sebelumnya

b. Moving Average (Rata-rata Bergerak)

Moving average merupakan metode peramalan yang menggunakan rata-rata historis aktual dibeberapa periode terakhir untuk peramalan periode berikutnya. Dalam peramalan ini, diasumsikan permintaan pasar 
tetap stabil. Secara matematis, moving average dirumuskan sebagai berikut:

$$
\begin{aligned}
& F_{t}= \frac{\sum \text { Permintaan dalam periode n sebelumnya }}{n} \\
& \text { keterangan: } \\
& \mathrm{Ft}=\text { peramalan } \\
& \text { permintaan periode berikutnya } \\
& \mathrm{N}=\text { jumlah periode } \\
& \text { dalam Moving Average } \\
& \text { c. Weighted Moving Averages } \\
& \text { (Rata-rata Begerak dengan } \\
& \text { Bobot) } \\
& \text { Secara sistematis, weighted } \\
& \text { moving average dapat } \\
& \text { dinyatakan sebagai berikut: }
\end{aligned}
$$

$F_{t}$

$=\frac{\sum(\text { bobot pada periode } n)(\text { permintaan data pada periode } n)}{\sum \text { bobot }}$

keterangan:

$\mathrm{Ft}=$ peramalan permintaan periode berikutnya

Pemilihan bobot merupakan hal yang tidak pasti karena tidak ada rumus untuk menetapkannya.

d. Exponential Smoothing (pemulusan eksponensial)

Exponential Smoothing merupakan metode peramalan rata-rata bergerak dengan pembobotan, di mana $\alpha$ adalah sebuah bobot atau konstanta penghalusan yang dipilih oleh peramal yang mempunyai nilai antara 0 dan 1 . Menurut akhmad (2018:75) metode peramalan eksponensial menarik untuk aplikasi produksi dan opersi yang menyangkut peramalan sejumlah besar item. Secara sistematis, metode exponential smoothing dirumuskan sebagai berikut:

$F_{t}=F_{t-1}+\alpha\left(A_{t-1}-F_{t-1}\right)$

keterangan:

$\mathrm{Ft}=$ peramalan permintaan di periode berikutnya

$\mathrm{Ft}-1=$ peramalan permintaan di periode sebelumnya

At $-1=$ permintaan aktual di periode sebelumnya

$\alpha=$ konstanta eksponensial $(0 \leq \alpha \leq 1)$

e. Exponential Smoothing with Trend

Adjusment

(Penghalusan Eksponensial dengan Tren)

Seperti halnya dengan teknik rata-rata bergerak, metode eksponensial sederhana gagal merespon trend. Untuk menghaluskan koreksi trend, maka dapat dihitung ramalan penghalusan eksponensial, dan kemudian disesuaiakan 
untuk kelambanan positif dan negatif. Metode eksponensial sederhana sering disebut sebagai penghalusan tingkat pertama, dan penghalusan yang disesuaikan-trend disebut penghalusan tingkat kedua, atau berganda.

Penghalusan eksponensial yang disesuaikan adalah ramalan penghalusan eksponensial sederhana dengan menambahkan dua konstanta penghalusan $\boldsymbol{\alpha}$ untuk rata-rata dan $\beta$ untuk tren. Rumus peramalan dengan penghalusan eksponensial dengan tren sebagai berikut:

$F I T_{t}=F_{t}+T_{t}$

$F_{t}=\alpha\left(A_{t-1}\right)+(1-\alpha)\left(F_{t-1}+T_{t-1}\right)$

$T_{t}=\beta\left(F_{t}+T_{t-1}\right)+(1-\beta) T_{t-1}$

keterangan:

FITt = peramalan dengan tren

$\mathrm{Ft} \quad=$ peramalan dengan eksponensial yang dihaluskan dari data berseri pada periode $\mathrm{t}$

$\mathrm{Ft}-1=$ peramalan dengan eksponensial yang dihaluskan dari data berseri

pada periode $\mathrm{t}-1$

$\mathrm{Tt}=$ tren dengan eksponensial yang dihaluskan pada periode $\mathrm{t}$
$\mathrm{Tt}-1=$ tren dengan eksponensial yang dihaluskan pada periode $\mathrm{t}-1$

At $-1=$ permintaan aktual pada periode $\mathrm{t}-1$

$\alpha=$ konstanta penghalusan untuk rata-rata $(0$ $\leq \alpha \leq 1)$

$\beta=$ konstanta penghalusan untuk rata-rata ( $0 \leq \beta \leq 1)$

f. Trend Projection (Proyeksi Tren)

Metode yang digunakan untuk mencocokkan garis tren pada serangkaian data masa lalu, kemudian memproyeksikan garis pada masa depan untuk peramalan jangka menengah atau jangka panjang. Garis tren pada metode proyeksi tren dapat dinyatakan dengan persamaan sebagai berikut:

$$
y=a+b x
$$

keterangan:

$\mathbf{y}=$ variabel terikat yang akan diprediksi

a $=$ persilangan sumbu

y

$\mathrm{b}=$ kemiringan garis regresi

$\mathrm{x} \quad=$ variabel bebas

\subsection{Ukuran Akurasi Hasil}

\section{Peramalan}

Akurasi perhitungan dari keseluruhan peramalan di setiap 
model peramalan dapat dijelaskan dengan membandingkan nilai yang diramal dengan nilai aktual atau nilai yang sedang diamati. Menurut Heizer dan Render (2017:145), jika Ft melambangkan peramalan pada periode $\mathrm{t}$, dan At melambangkan permintaan aktual pada periode $\mathrm{t}$, maka kesalahan peramalan (forecast error) adalah sebagai berikut:

Kesalahan peramalan (forecast error) = permintaan actual-nilai peramalan

$$
E_{t}=F_{t}-A_{t}
$$

Sejalan dengan pendapat di atas, Nasution \& Prasetyawan (2008:34) menjelaskan bahwa ada 4 ukuran yang bisa digunakan untuk mengukur akurasi hasil peramalan, yaitu:

\section{MAD (Mean Absolute Deviation)}

MAD merupakan rata-rata kesalahan mutlak selama periode tertentu tanpa memperhatikan apakah hasil peramalan lebih besar atau lebih kecil dibandingkan kenyataannya.

Secara matematis, MAD dirumuskan sebagai berikut:

$$
M A D=\Sigma\left|\frac{A_{t}-F_{t}}{n}\right|
$$

keterangan:

At $=$ permintaan aktual pada periode-t

$\mathrm{Ft}=$ peramalan permintaan pada periode-t

$\mathrm{n} \quad=$ jumlah periode peramalan yang terlibat

\section{MSE (Mean Square Error)}

MSE dihitung dengan menjumlahkan kuadrat semua kesalahan peramalan pada setiap periode dan membaginya dengan jumlah periode peramalan. Secara matematis, MSE dirumuskan sebagai berikut:

$$
M S E=\Sigma \frac{\left(A_{t}-F_{t}\right)^{2}}{n}
$$

\section{MAPE (Mean Percentage Error)}

MAPE biasanya lebih berarti dibandingkan MAD karena MAPE menyatakan persentase kesalahan hasil peramalan terhadap permintaan aktual selama periode tertentu yang akan memberikan informasi persentase kesalahan. Secara matematis, MAPE dirumuskan sebagai berikut:

$$
M A P E=\left(\frac{100}{n}\right) \Sigma\left|A_{t}-\frac{F_{t}}{A_{t}}\right|
$$




\subsection{Kerangka Pemikiran}

Setiap perusahaan mengalami naik turun dalam permintaan suatu produknya, umumnya permintaan konsumen terhadap produknya selalu berubah-ubah dalam setiap periode. Dengan adanya ketidakpastian suatu permintaan, perusahaan perlu membuat suatu ramalan permintaan. Dimana untuk membuat ramalan tersebut diperlukan suatu data historis pada periode-periode sebelumnya. data historis yang digunakan yaitu data penjualan produk galvalum selama bulan Oktober 2017 sampai september 2018 untuk meramalkan permintaan periode yang akan datang. sehingga bentuk gambaran dari penelitian ini bisa dilihat di Gambar 1 dibawah ini:

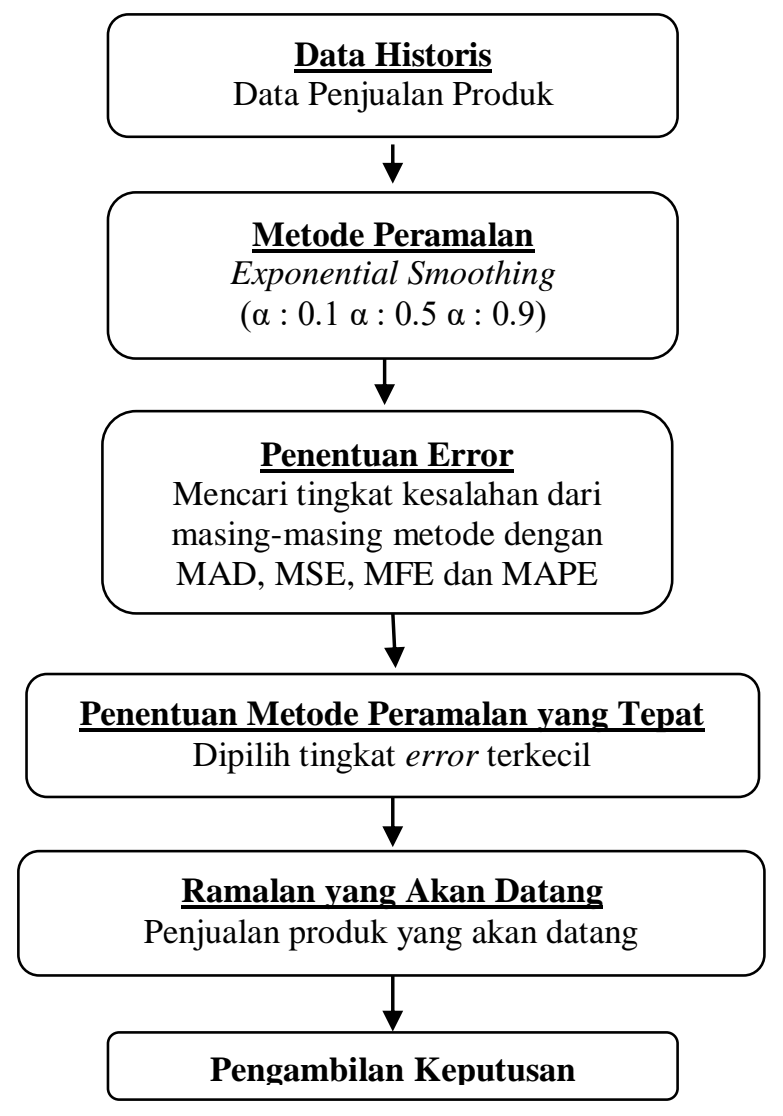

Gambar 1. Kerangka Pemikiran 


\section{METODE PENELITIAN}

Penelitian ini merupakan penelitian kuantitatif dengan pendekatan diskriptif merupakan penelitian yang berusaha mendeskripsikan hasil perhitungan statistik yang berupa angka-angka dan tabel sesuai dengan situasi dilapangan dengan cara menghitung data historis penjualan yang terjadi pada bulan Oktober 2017 sampai September 2018 untuk mengambil kesimpulan. Unit analisis dalam penelitian ini adalah data penjualan produk baja ringan (Galvalum) pada Toko Istana Galvalum Kecamatan Ajung-Jember. Lokasi penelitian Toko Istana Galvalum Jember Jl. Otto Iskandar Dinata no.36 AjungJember.

Populasi dan sampel dalam penelitian ini adalah seluruh data penjualan produk baja ringan (Galvalum) di Toko Istana Galvalum mulai dari bulan Januari 2016 sampai September 2018, sehingga jumlah populasinya yaitu 33 bulan. Teknik pengambilan sampel dalam penelitian ini adalah purposive sampling. Sampel yang digunakan berdasarkan kriteria peneliti yaitu data penjualan mulai bulan Oktober 2017 sampai dengan September 2018. Sehingga total sampel yang digunakan dalam penelitian ini adalah 12 bulan.

Sumber data yang digunakan dalam penelitian ini adalah data sekunder berupa data penjualan baja ringan (galvalum) mulai bulan Oktober 2017 sampai dengan September 2018.

Metode analisis yang digunakan dalam penelitian ini adalah metode Exponential Smoothing dengan alpha ( $\alpha: 0.1 \alpha: 0.5 \alpha: 0.9)$ dengan bantuan software POM QM (Quantitative Methodes) for Windows 5.2 sebagai pengelola datanya. Selanjutnya metode tersebut diukur tingkat kesalahan peramalan dengan menggunakan MSE (Mean Squared Error), MAD (Mean Absolute Deviation), MFE (Mean Forcast Error), dan MAPE (Mean Absolute Precentage Error). 


\section{HASIL PENELITIAN DAN PEMBAHASAN}

Data penjualan Toko Istana penjualan adalah sebagaimana Galvalum pada data historis digambarkan pada Tabel berikut ini:

Tabel 2. Data Penjualan Kanal C 1 mm

\begin{tabular}{|c|c|c|c|c|}
\hline No & Bulan & Unit & Harga & Jumlah \\
\hline 1 & Oktober & 533 & Rp. 110.000 & Rp. 58.630 .000 \\
\hline 2 & November & 831 & Rp. 110.000 & Rp. 91.410 .000 \\
\hline 3 & Desember & 945 & Rp. 110.000 & Rp. 103.950 .000 \\
\hline 4 & Januari & 1777 & Rp. 110.000 & Rp. 195.470 .000 \\
\hline 5 & Februari & 1093 & Rp. 110.000 & Rp. 120.230 .000 \\
\hline 6 & Maret & 2466 & Rp. 110.000 & Rp. 271.260 .000 \\
\hline 7 & April & 1199 & Rp. 110.000 & Rp. 131.890 .000 \\
\hline 8 & Mei & 2673 & Rp. 110.000 & Rp. 294.030 .000 \\
\hline 9 & Juni & 831 & Rp. 110.000 & Rp. 91.410 .000 \\
\hline 10 & Juli & 433 & Rp. 110.000 & Rp. 47.630 .000 \\
\hline 11 & Agustus & 736 & Rp. 110.000 & Rp. 80.960 .000 \\
\hline 12 & September & 1048 & Rp. 110.000 & Rp. 115.280 .000 \\
\hline
\end{tabular}

Sumber : Data penjualan Toko Istana Galvalum, 2017 - 2018

Berdasarkan Tabel 2, penjualan produk Kanal C $1 \mathrm{~mm}$ paling tinggi terjadi pada bulan Mei 2018 yaitu sebesar 2673 unit. Menurut kepala toko peningkatan penjualan produk Kanal C $1 \mathrm{~mm}$ dikarena Toko Istana
Galvalum selain pengecer juga sebagai distributor dari produk Osaka Stell sehingga pada bulan Mei 2018 banyak toko pengecer yang membeli produk Kanal C $1 \mathrm{~mm}$ untuk dijual kembali.

\subsection{Metode Exponential Smoothing Produk Kanal C $1 \mathrm{~mm}$ dengan alpha ( $\alpha$ :}

$$
0.1, \alpha: 0.5, \alpha: 0.9)
$$

Berdasarkan Tabel 2, hasil perhitungan peramalan penjualan produk Kanal C $1 \mathrm{~mm}$ untuk bulan Oktober 2018 dengan metode Exponential Smoothing dengan alpha
0.1 yaitu 1005.54 dengan ukuran tingkat kesalahan nilai MSE sebesar 756930.3, nilai MAD sebesar 657.39, nilai MFE sebesar 429.58 dan nilai MAPE sebesar $51.48 \%$. 
Tabel 2. Hasil Metode Exponential Smoothing

Produk Kanal C $1 \mathrm{~mm}$ dengan alpha 0.1

\begin{tabular}{|l|c|}
\hline \multicolumn{1}{|c|}{ Measures } & Value \\
\hline Error Measures & 429,58 \\
\hline Bias (Mean Error) & 657,39 \\
\hline MAD (Mean Absolute Deviation) & NA \\
\hline MSE (Mean Squared Error) & $51,48 \%$ \\
\hline Standard Error (denom=n-2=-2) & 1005,54 \\
\hline MAPE (Mean Absolute Percent Error) & \\
\hline Forecast & \\
\hline Next period & \\
\hline Sumber: Data Penjualan Produk Kanal C 1 & \\
\hline
\end{tabular}

Sumber : Data Penjualan Produk Kanal C 1 mm yang diolah (2018)

Tabel 3. Hasil Metode Exponential Smoothing

Produk Kanal C $1 \mathrm{~mm}$ dengan alpha 0.5

\begin{tabular}{|l|c|}
\hline \multicolumn{1}{|c|}{ Measures } & Value \\
\hline Error Measures & 74,89 \\
\hline Bias (Mean Error) & 681,65 \\
\hline MAD (Mean Absolute Deviation) & 656971,30 \\
\hline MSE (Mean Squared Error) & NA \\
\hline Standard Error (denom=n-2=-2) & $65,64 \%$ \\
\hline MAPE (Mean Absolute Percent Error) & 944,92 \\
\hline Forecast & \\
\hline Next period & \\
\hline
\end{tabular}

Sumber : Data Penjualan Produk Kanal C 1 mm yang diolah (2018)

Berdasarkan Tabel 3, hasil perhitungan peramalan penjualan produk Kanal C $1 \mathrm{~mm}$ untuk bulan Oktober 2018 dengan metode Exponential Smoothing dengan alpha 0.5 yaitu 944.92 dengan ukuran tingkat kesalahan nilai MSE sebesar 656971.3, nilai MAD sebesar 681.65, nilai MFE sebesar 74.89 dan nilai MAPE sebesar $65.64 \%$. 
Tabel 4. Hasil Metode Exponential Smoothing

Produk Kanal C $1 \mathrm{~mm}$ dengan alpha 0.9

\begin{tabular}{|l|r|}
\hline \multicolumn{1}{|c|}{ Measures } & Value \\
\hline Error Measures & 48,62 \\
\hline Bias (Mean Error) & 777,64 \\
\hline MAD (Mean Absolute Deviation) & 859751,80 \\
\hline MSE (Mean Squared Error) & NA \\
\hline Standard Error (denom=n-2=-2) & $68,59 \%$ \\
\hline MAPE (Mean Absolute Percent Error) & \\
\hline Forecast & 1014,34 \\
\hline Next period & \\
\hline Sunber : Dat Penjualan Produk Kanal C 1 & \\
\hline
\end{tabular}

Sumber : Data Penjualan Produk Kanal C $1 \mathrm{~mm}$ yang diolah (2018)

Berdasarkan Tabel 4, hasil 0.9 yaitu 1014.33 dengan ukuran perhitungan peramalan penjualan tingkat kesalahan nilai MSE sebesar produk Kanal C $1 \mathrm{~mm}$ untuk bulan 859751.8, nilai MAD sebesar Oktober 2018 dengan metode 777.64, nilai MFE sebesar 48.62 dan Exponential Smoothing dengan alpha nilai MAPE sebesar $68.59 \%$.

\subsection{Metode Peramalan yang Terbaik Produk Kanal C 1 mm}

Berdasarkan hasil penerapan metode peramalan kuantitatif peramalan yang terbaik menunjukkan bahwa metode exponential Smoothing a : 0.1 merupakan metode peramalan yang terbaik, karena metode tersebut menghasilkan nilai MSE (Mean Square Error), MAD (Mean
Absolute Deviation), MFE (Mean Forcast Error), dan MAPE (Mean Absolute Percentage Error) terkecil dibandingkan dengan metode lainnya. Tabel 5 menunjukkan hasil perhitungan beberapa metode peramalan penjualan Toko Istana Galvalum Produk Kanal C $1 \mathrm{~mm}$. 
Tabel 5. Forcast Eror Produk Kanal C 1 mm

\begin{tabular}{|c|c|c|c|c|c|c|}
\hline \multicolumn{2}{|c|}{ Kanal C 1 mm } & MSE & MAD & MFE & MAPE & $\begin{array}{c}\text { Ramalan } \\
\text { Bulan Oktober } \\
2018\end{array}$ \\
\hline \multirow{2}{*}{$\begin{array}{c}\text { Exponential } \\
\text { Smoothing }\end{array}$} & $\alpha: 0.1$ & 756930.30 & 657.39 & 429.58 & $51.48 \%$ & 1005.54 \\
\cline { 2 - 7 } & $\alpha: 0.5$ & 656971.30 & 681.65 & 74.89 & $65.64 \%$ & 944.92 \\
\cline { 2 - 7 } & $\alpha: 0.9$ & 859751.80 & 777.64 & 48.62 & $68.59 \%$ & 1014.33 \\
\hline
\end{tabular}

Sumber : Data Penjualan Produk Kanal C $1 \mathrm{~mm}$ yang diolah (2018)

Berdasarkan Tabel 5 diatas, memilki tingkat kesalahan lebih

diketahui bahwa hasil perhitungan dengan metode exponential

Smoothing a : 0.1 lebih baik dan lebih cocok diterapkan oleh Toko Istana Galvalum dalam meramalkan penjualan baja ringan (galvalum) produk Kanal C $1 \mathrm{~mm}$ pada bulan Oktober 2018, karena metode Exponential Smoothing alpha 0.1

\section{KESIMPULAN DAN SARAN}

\subsection{Kesimpulan}

Hasil yang diambil sebagai kesimpulan adalah hasil yang dinilai paling rendah untuk kategori MSE, MAD, MFE dan MAPE setiap metode yang digunakan. Keempat hal inilah yang akan digunakan sebagai bahan pertimbangan dalam menentukan metode peramalan yang terbaik pada Toko Istana Galvalum jember dalam menyusun perencanaan pengadaan barang rendah dibandingkan kedua metode diatas. adapun tingkat kesalahan peramalan, MSE sebesar 756930.30, MAD sebesar 657.39, MFE sebesar 429.58, dan MAPE sebesar 51.48\% dengan hasil peramalan untuk bulan Oktober 2018 sebesar 1005.54 jika dibulatkan menjadi 1006 unit.

produk Kanal C $1 \mathrm{~mm}$, Kanal C 0.75, Kanal C $0.6 \mathrm{~mm}$, Reng dan Baut Skrup untuk bulan Oktober 2018.

1. Metode peramalan terbaik berdasarkan nilai MSE, MAD, MFE dan MAPE yang paling rendah untuk produk Kanal C 1 mm yaitu menggunakan metode Exponential Smoothing dengan alpha 0.1 karena memiliki nilai MSE sebesar 756930.30, MAD 
sebesar 657.39, MFE sebesar 429.58, dan MAPE sebesar $51.48 \%$ dengan hasil peramalan untuk bulan Oktober 2018 sebesar 1005.54 jika dibulatkan menjadi 1006 unit.

2. Metode peramalan terbaik berdasarkan nilai MSE, MAD dan MAPE yang paling rendah untuk produk Kanal C $0.75 \mathrm{~mm}$ yaitu menggunakan metode Exponential Smoothing dengan alpha 0.9 karena memiliki nilai MSE sebesar 655615.40, MAD sebesar 698.26, MFE sebesar 92.46, dan MAPE sebesar $15.18 \%$ dengan hasil peramalan untuk bulan Oktober 2018 sebesar 6547 unit.

3. Metode peramalan terbaik berdasarkan nilai MSE, MAD dan MAPE yang paling rendah untuk produk Kanal C $0.6 \mathrm{~mm}$ yaitu menggunakan metode Exponential Smoothing dengan alpha 0.1 karena memiliki nilai MSE sebesar 377299.00, MAD sebesar 743.00, MFE sebesar 297.97 dan MAPE sebesar $26.98 \%$ dengan hasil peramalan untuk bulan Oktober 2018 sebesar 1564 unit.

4. Metode peramalan terbaik berdasarkan nilai MSE, MAD dan MAPE yang paling rendah untuk produk Reng yaitu menggunakan metode Exponential Smoothing dengan alpha 0.9 karena memiliki nilai MSE sebesar 4256308, MAD sebesar 1848.92, MFE sebesar 370.98, dan MAPE sebesar $15.55 \%$ dengan hasil peramalan untuk bulan Oktober 2018 sebesar 15066 unit.

5. Metode peramalan terbaik berdasarkan nilai MSE, MAD dan MAPE yang paling rendah untuk produk Baut Skrup yaitu menggunakan metode Exponential Smoothing dengan alpha 0.5 karena memiliki nilai MSE sebesar 1206280000, MAD sebesar 26751.21, MFE sebesar 11996.72, dan MAPE sebesar $25.31 \%$ dengan hasil peramalan untuk bulan Oktober 2018 sebesar 112982.00 jika dibulatkan menjadi 112982 unit. 


\subsection{Saran}

Berdasarkan hasil analisis data dan kesimpulan maka dapat dikemukakan saran-saran sebagai bahan pertimbangan Toko Istana Galvalum Jember dalam menentukan kebijakan dalam hal peramalan penjualan rangka atap baja ringan (Galvalum). adapun saran-saran penulis adalah sebagai berikut:

1. Dikarenakan Toko Istanan Galvalum Jember selama ini tidak menggunakan metode peramalan untuk menyusun perencanaan persediaan barang dan cenderung lebih menggunakan metode naive, maka Toko Istanan Galvalum Jember dapat menerapkan metode peramalan untuk membantu menyusun perencanaan persediaan barang.

DAFTAR PUSTAKA

Adisaputro, Gunawan. 2014. Manajemen pemasaran Analisis untuk Perancangan Strategi Pemasaran. Yogyakarta: UPP STIM YKPN.

Akhmad. 2018. Manajemen Operasi. Edisi Pertama. Bogor: Azkiya Publishing.
2. Untuk

mempermudah peramalan penjualan disarankan agar perusahaan menggunakan perangkat lunak (software) seperti POM QM for Windows serta bagian khusus yang menangani peramalan penjualan, sehingga hasilnya dapat meningkatkan kesempatan perusahaan memperoleh laba.

3. Hasil dari peramalan dalam penelitian ini dapat dijadikan dasar dalam pengambilan keputusan strategis sebagai dasar perencanaan penjualan rangka atap baja ringan (Galvalum) untuk bulan Oktober 2018. Sedangkan untuk melengkapi penelitian ini ada baiknya dilakukan penelitian lanjutan mengenai peramalan untuk bulan selanjutnya.

Azwar, S. 2005. Sikap Manusia, Teori dan Pengukurannya. Yogyakarta: Pustaka Pelajar.

Baroto, Teguh. 2002. Perencanaan dan pengendalian Produksi. Jakarta: Ghalia Indonesia.

Basu Swastha DH. 2004. Asas-asas Marketing. Edisi 3. Yogyakarta: Liberty. 
Hartini, Sri. 2011. Evaluasi Pembelajaran. Surakarta: Qinant.

Heizer, Jay dan Render, Barry. 2015. Manajemen Operasi : Manajemen Keberlangsungan dan Rantai Pasokan, edisi 11. Jakarta: Salemba Empat. 2017. Operations Management. Twelfth Edition Pearson. New Jersey, USA.

Herjanto, Eddy. 2007. Manajemen Produksi dan Operasi. Cetakan Ketiga, Jakarta: PT. Grasindo.

Mulyadi. 2008. Sistem Akuntansi. Jakarta: Salemba Empat.

Nafarin, M. 2001. Penganggaran Perusahaan. Edisi Pertama. Jakarta: Penerbit Salemba.

Nasution, A. H. 2003. Perencanaan dan Pengendalian Produksi. Cetakan kedua. Surabaya: Guna Widya.

Rudianto. 2009. Akuntansi Manajemen. Yogyakarta: Grasindo.

Rusdiana, A. 2014. Manajemen Operasi. Bandung : CV. Pustaka Setia.

Sugiarto dan Harijono. 2000. Peramalan Bisnis. Jakarta: PT Gramedia Pustaka Utama.

Sugiyono. 2014. Metode Penelitian Kuantitatif, Kualitatif dan $R \& D$. Bandung:Alfabeta.

Stevenson, William J. 2018. Management Operation. UK: Prentice Hall.

Wignjosoebroto, S. 2003. Ergonomi, Studi Gerak, dan Waktu: Teknik Analisis untuk Peningkatan Produktivitas Kerja. Edisi pertama. Cetakan ketiga. Surabaya: Guna Widya.

Jurnal :
Arminas, dan Karanga, F.T. 2016. " Analisis Peramalan Penjualan Conforta's Bed Jenis Super Star Pada PT. Masindo Terang Perkasa Makassar". Politeknik ATI Makassar. Jurnal Teknik Industri Agro. p-ISSN : 2407 1846.

https://jurnal.umj.ac.id/index.p $\mathrm{hp} / \mathrm{semnastek} /$ article/download/ 750/695. Diakses Tanggal 25 April 2019. Jam 12.30

Yanti, N.P.L.P. Tuningrat, I.A.M dan Wiranatha, A.A.P.A.S. 2016. "Analisis Peramalan Penjualan Produk Kecap Pada Peusahaan Kecap Manalagi Denpasar Bali”. Universitas Udayana. Jurnal rekayasa dan manajemen agroindustri. Vol. 4 No. 1 Hal : $72-81$. https://scholar.google.com/citat ions?user=PAfIhT0AAAAJ\&hl =en. Diakses Tanggal 25-122018. Jam 11.00

Wardah, Siti dan Iskandar, 2016. "Analisis peramalan penjualan produk kripik pisang kemasan bungkus". Riau: Universitas Islam Indragiri. Jurnal Teknik Industri. Vol. 11 No. 3 Hal : 135 -142 . https://ejournal.undip.ac.id/inde x.php/jgti/article/view/12939/9 719. Diakses Tanggal 25-122018. Jam 15.30 